\title{
Baldíos, derechos posesorios y tierra realenga en el primer proceso de composición en el distrito de Charcas. Virreinato del Perú, 1591-1597
}

\section{Baldíos, possession rights and royal land during the first composición process in Charcas. Viceroyalty of Peru, 1591-1597}

${ }^{1}$ Consejo Nacional de Investigaciones Científicas y Técnicas, Buenos Aires, Argentina.

*Correspondencia: jurado_carolina@yahoo.com.ar

Resumen. A partir de un corpus documental diverso, que incluye disposiciones regias, correspondencia vicerregia, pareceres locales y el juicio de residencia del juez de composición Osores de Ulloa, este artículo explora la figura jurídica de las tierras baldías e indaga en las relaciones posesorias que distintos vecinos ejercieron en ellas en el distrito de Charcas (virreinato del Perú) en la década de 1590. En ese sentido, se propone que, si hasta la década de 1580 las esferas virreinales peruanas propiciaban el uso común y el reparto gracioso de los baldíos, la primera composición y venta de tierras, ordenada por reales cédulas de 1591, tuvo un papel central en el reforzamiento del dominio regio sobre las tierras baldías y sobre las tierras indígenas consideradas vacantes, a partir del accionar de los jueces comisionados que en el terreno dotaron de referente material a una noción jurídica en disputa.

CÓMO CITAR: Jurado, C. (2022). Baldíos, derechos posesorios y tierra realenga en el primer proceso de composición en el distrito de Charcas. Virreinato del Perú, 1591-1597. América Latina en la Historia Económica, 29(1), 1-24. DOI: $10.18232 / 20073496.1253$ 
Palabras clave: recursos agrarios; oficiales reales; comunidades indígenas; virreinato del Perú.

Abstract. Based on the analysis of a rich documentary corpus, including royal dispositions, viceroyal letters, reports and the residencia of the Charcas judge of composición Osores de Ulloa, this article explores the legal notion of baldios and it analyzes the possessory relations exercised in Charcas (viceroyalty of Peru) in the 1590s. It proposes that, if until the 1580s Peruvian viceroyal spheres favored common use and graceful distribution of baldios, the first composición de tierras ordered by 1591 royal dispositions played a significant role in the reinforcement of royal domain of baldios and "vacant" indigenous lands, taking into account judges actions which provided material reference to a disputed legal notion.

Key words: agrarian resources; royal officials; indians; viceroyalty of Peru.

JEL: N46; N96.

Recibido: 22 de septiembre de 2020

Aceptado: 10 de febrero de 2021

Publicado: 23 de agosto de 2021.

\section{INTRODUCCIÓN}

Los derechos de la monarquía castellana sobre las tierras baldías de los virreinatos americanos constituyen un aspecto nodal abordado por disposiciones regias y juristas del ius commune con el fin de asentar la legitimidad de la corona sobre las mismas. Sin soslayar el reconocimiento teológico y jurídico de la corona a la legitimidad del dominio indígena sobre sus tierras, a mediados del siglo XviI Juan de Solórzano (1972) sintetizaba en su Política indiana que, en los territorios americanos, los "baldíos y aguas pertenecen al fisco" (p. 480). De este modo, los montes, tierras, pastos y aguas contenidos dentro de los límites precisados en el Tratado de Tordesillas y que no fueran posesión comunal indígena se encontraban entre las regalías del monarca castellano por los títulos emanados de las bulas pontificias y derecho de conquista. Lo anterior fundaba la legitimidad de la corona a distribuir la tierra realenga entre los particulares, como realizó tempranamente a partir de capitulaciones firmadas con los conquistadores y mediante cédulas de gracia o merced. En una frase comúnmente citada en la historiografía, Solórzano Pereira recogía la elaboración jurídica y las experiencias americanas de más de un siglo al afirmar que "todo lo demás de este género [tierras, prados, pastos, montes y aguas] y especialmente lo que estuviere por romper y cultivar es y debe ser de su Real Corona y dominio" (p. 480).

Se propone en este trabajo que la definición de tierras baldías plasmada jurídicamente en el año 1648 para los territorios americanos -como tierras por romper y cultivar-contiene y resulta de un complejo proceso histórico de disputa por el referente semántico y material del término y por las prácticas posesorias de los recursos agrarios en los virreinatos americanos, en el cual el año 1591 tuvo un sitio insoslayable. Ese año, por real cédula del 1 de noviembre, la corona enfatizó la legitimidad de su dominio eminente sobre las tierras americanas, con excepción de aquellas bajo dominio indígena, por "haber Nos sucedido en el señorío de las Indias y pertenecer a nuestro patrimonio y Corona real los baldíos y tierras que no estuvieren concedidos" (Recopilación, libro IV, título xII, ley xIV, 1996). La argumentación anterior fundamentaba el examen de los títulos de tierras en manos hispano-criollas, la restitución de aquellas ocupadas de modo irregular o su composición - esto es, el pago a la Real Hacienda de una cantidad concertada a cambio de una titulación adecuada-, promoviendo la venta de las tierras baldías y la reestructuración de los espacios 
urbanos y de la territorialidad de las comunidades indígenas en las posesiones ultramarinas del continente americano. El examen en el terreno quedaba a cargo de jueces de comisión itinerantes, nombrados en el virreinato del Perú por don García Hurtado de Mendoza, segundo marqués de Cañete (1590-1596). Si bien el virrey otorgaba los títulos definitivos de las tierras examinadas, en un procedimiento que reforzaba los lazos de lealtad de los súbditos con las esferas vicerregias (Jurado, 2017), fueron los jueces de comisión quienes, al seleccionar los casos en lo local, cuestionaron a su paso derechos posesorios ejercidos en tierras realengas y otras conceptuadas como baldías y dotaron de contenido material a una categoría histórico-jurídica peninsular, como lo era el baldío, implementada en los contextos virreinales americanos.

Desde la década de 1940, investigaciones vinculadas a la historia clásica del derecho analizaron los procesos de composición y venta de tierras en el virreinato del Perú focalizando en el impulso dado desde las reales cédulas de 1591 a la adjudicación de tierras baldías o realengas en pública subasta, en tanto ramo de la Real Hacienda. Con la Recopilación de Leyes de Indias y las obras de los juristas Solórzano Pereyra y Gaspar de Escalona Agüero como principal corpus documental, las regalías y las tensiones dicotómicas entre los intereses de la corona y de los particulares -entendidos anacrónicamente como "público", "privado"- en torno a las tierras estuvieron en el centro de sus análisis (Mariluz, 1978; Ots, 1946, 1959). En cambio, a partir de procesos judiciales entablados por las comunidades indígenas, posteriores trabajos históricos y etnohistóricos incluyeron nuevos actores sociales y enfatizaron el papel de las composiciones para legitimar el traspaso a manos hispano-criollas de las tierras usurpadas a los repartimientos de indios. En muchas ocasiones, la búsqueda por recomponer la territorialidad de los colectivos indígenas primó sobre el análisis de las reales cédulas de 1591, sobre la definición jurídica de las tierras realengas y baldías en los contextos virreinales y su relación con las tierras de dominio indígena (Glave, 2009; Jurado, 2014b, 2018; Palomeque, 2010; Platt, Bouysse-Cassagne y Harris, 2006; Río, 2005).

En ese sentido, ponderando la reflexión y el accionar de los jueces de comisión, este trabajo propone explorar los papeles de las tierras baldías y las tierras realengas durante la primera composición y venta de tierras en el virreinato del Perú, considerando los "derechos de propiedad" como productos históricos que reflejan las relaciones sociales en torno a las cosas y no entre los individuos y las cosas (Izquierdo, 2007). Para ello, a continuación, se examinan la pluralidad semántica y la transformación histórica del término tierras baldías en la península y en el virreinato del Perú del siglo XVI, a partir del análisis de disposiciones regias y correspondencia de las esferas virreinales. Luego, se subrayan los modos en los que las definiciones brindadas en las reales cédulas de 1591, así como en textos escritos del entorno vicerregio contextualizan el término analizado y sus posibles referentes materiales en la praxis judicial. Para ello, se incorpora documentación inédita referida a la interpretación que el letrado de los indios Alberto de Acuña y el deán Pedro Muñiz realizaron de las disposiciones reales y de su incipiente ejecución a solicitud del virrey. Por último, a partir del análisis de las imputaciones y los descargos contenidos en la residencia de don Pedro Osores de Ulloa, se analiza el accionar en materia de derechos posesorios del segundo juez de comisión designado para aplicar las reales cédulas de 1591 en el distrito de Charcas y las definiciones que se esgrimieron desde una mirada local. 


\section{CARACTERÍSTICAS DE LAS TIERRAS BALDÍAS EN EL CONTEXTO PENINSULAR}

En la península, una profunda conflictividad agraria entre la corona, los concejos, los señores y las aldeas en torno a reclamos de dominio sobre tierras de uso no intensivo y titularidad difusa subyacía al término tierras baldías. Los monarcas castellanos habían adoptado del derecho romano la idea según la cual todo bien sin dueño (bona vacantia) pertenecía a la corona. Así, todas las tierras que no habían sido formalmente concedidas por la monarquía luego de la conquista y repoblación del territorio árabe continuaban siendo tierras realengas (Vassberg, 1983). Lo anterior se combinaba con la figura jurídica conforme a la cual el rey era el titular por derecho de guerra de las tierras yermas, tierras que no estaban pobladas -en una doble significación de población y cultivo-, designadas también como baldíos. En ese sentido, se ha señalado que su rasgo central radicaba en la carencia de un titular efectivo, lo que justificaba la innegable regalía sobre los territorios yermos del reino (Domínguez, 1933). Los conflictos agrarios, en especial por el control de los comunales concejiles, se acrecentaron desde mediados del siglo xIV y la implementación de las Leyes de Toledo (1480) -que procuraban la reversión a pastos de tierras de uso comunal roturadas sin permiso de los concejos urbanos- convivió con la legalización regia de las usurpaciones y la subasta de tierras de titularidad real. Estas oscilaciones del comportamiento de la monarquía en relación con la propiedad concejil -terrenos de uso libre, pero de dominio eminente del rey- expresaban no sólo las coyunturas económicas, sino también la búsqueda por mantener un balance de fuerzas favorables al ordenamiento político-económico de cada región (Luchía, 2008). Sin embargo, el papel central ejercido por la monarquía en la resolución de los conflictos durante todo el siglo XVI demostró a la corona la indefinición y los vacíos en la caracterización de los términos comunales y le permitió ejercitarse en la atribución de una titularidad superior sobre tierras que carecían de un uso específico (Izquierdo y Sánchez, 1998).

Aún en el siglo Xvi el término tierras baldías no tenía un significado unívoco. De acuerdo con David Vassberg (1983), podía referir tanto a tierras realengas que no habían sido concedidas y permanecían sin utilizar, como a parcelas de tierras realengas que habían sido ocupadas para uso particular sin una concesión real específica, incluso si esa ocupación era tan antigua que la tierra se trataba como dominio de un particular. Asimismo, las tierras que los concejos municipales utilizaban de manera comunal fueron llamadas baldías, aunque se usaran de continuo y hubiesen sido otorgadas como concesión regia. En ese sentido, estas tierras, a pesar de incluirse bajo el mismo nombre, no serían desde su definición jurídica tierras realengas, aunque en la práctica la diferencia no era tan manifiesta de acuerdo con el autor. Finalmente, otro significado de baldío circulaba en la península a inicios del siglo xvi, como demuestran los escritos del fiscal y alcalde mayor de la Mesta Miguel Caxa de Leruela, quien utilizaba la palabra balda para designar las tierras donde no se cobraba renta por su uso (Vassberg, 1983). Asimismo, en sus análisis sobre los derechos comunales en Sevilla, Ma. Antonia Carmona (1995) subraya la existencia de un complejo proceso histórico tras la pluralidad semántica de la palabra baldío, con la consiguiente modificación de su significado. Así, mientras en el siglo xiII baldío designaba tierras que estaban baldías o sin cultivar, para finales del siglo xv indicaba los espacios que eran baldíos, es decir, de uso comunal, identificándose los baldíos con los concejos urbanos y, por otro lado, con las tierras realengas.

En los años 1557 y 1559, distintas causas -como las necesidades de metálico, el aumento demográfico o la conflictividad agraria- motivaron el interés de Felipe II por las primeras ventas de tierras realengas en sus dominios peninsulares (Izquierdo y Sánchez, 1998). Durante la década siguiente, se enviaron jueces de tierras con el fin de vender los baldíos a los ocupantes que mostraran 
disposición a comprar las tierras, quienes convenían el valor, la forma y los plazos de pago con el juez. De acuerdo con Vassberg (1983), la corte no tuvo una política definida sobre cuáles tierras de la amplia denominación de baldías debían ser vendidas y las disposiciones afectaron sólo los baldíos roturados -ya que el resto se reservaba para pastos-. Animado por la idea de vender las tierras a los que las trabajaban, el Consejo dudó acerca de la legitimidad de quitar las tierras a los que las poseían y no ofrecían un monto justo por ellas. Factores como la edad del poseedor, la cantidad de años que hubiese ocupado la tierra y el valor añadido a la misma en mejoras, problematizaron la desposesión; y el Consejo optó por quitarlas, pero compensando o indemnizando a los poseedores que perdieran las tierras. Sin embargo, esta actitud protectora no fue duradera, pues en la década de 1570 se instruyó expresamente a los jueces de tierras que no otorgaran ningún tipo de recompensa a los que no quisieran o no pudieran pagar lo exigido por las tierras (Vassberg, 1983). Si bien las ventas permitieron recaudar importantes ingresos, en especial en las zonas más ricas de Castilla -Andalucía, Zamora, Valladolid y las provincias de Toledo, Madrid y Guadalajara-, para 1590 la resistencia a la venta de baldíos, sobre todo por parte de las Cortes, había llegado a tal extremo que la corona suspendió el programa. Sin embargo, en noviembre de 1591, cuatro reales cédulas instruyeron a las autoridades de los virreinatos americanos la composición y venta de tierras en sus jurisdicciones, proceso que, aunque con los antecedentes mencionados, adquirió peculiaridades en el continente.

\section{Las tierras baldías en el virReinato del Perú hasta 1591}

Conquistadores, oficiales, vecinos y disposiciones de la monarquía castellana trasladaron al contexto americano el concepto de tierras realengas y baldías sobre las cuales la corona esgrimió derechos para su reparto entre los particulares. Existe consenso en la historiografía clásica de la historia del derecho respecto que, desde inicios de la conquista castellana, la corona compensó los servicios prestados por los conquistadores con dominio particular de las tierras con el objeto de instaurar una política de población. Bien mediante prerrogativas contenidas en capitulaciones entre el particular y la corona -que implicaban la recompensa del descubridor con grandes extensiones de tierras y la facultad de repartir solares entre su hueste-, o mediante reales cédulas de gracia o merced y provisiones generales y/o particulares, y, finalmente, mediante las ordenanzas de descubrimiento y nueva población [1573], las concesiones de tierras tuvieron un carácter gratuito y no oneroso. Pocos fueron los españoles que tuvieron un título emanado directamente del rey; en cambio, durante los primeros años, los cabildos gravitaron decisivamente en el otorgamiento de mercedes mientras que, desde 1558-1559, la corona fue limitando esas prerrogativas y desde 1572 privilegió a virreyes y presidentes de las reales audiencias para la adjudicación de tierras y solares (Solano, 1991). A cambio de la merced, se imponían determinados requisitos -entre los que figuraban un plazo para efectuar la ceremonia de posesión, la vecindad, el cultivo, la crianza de ganado o la construcción de edificaciones, entre otros-, cuyo cumplimiento perfeccionaba el dominio del particular (Mariluz, 1978; Ots, 1959). Asimismo, los repartos debían realizarse sin perjuicio de los naturales y debían afectar “tierras baldías”, sobre las cuales -al igual que en la península- la monarquía reclamaba dominio.

De modo simultáneo, la monarquía reconoció la legitimidad del dominio indígena sobre sus tierras. Es la presencia de esta "propiedad" indígena la que diferenció la política de baldíos y composiciones de tierras en los territorios virreinales americanos (Menegus, 1991). Durante las décadas de 1520 y 1530, la Segunda Escolástica en torno a la Universidad de Salamanca fue clave en la 
construcción jurídica y teológica del dominio indígena, de amplia influencia en la corte del rey Carlos I. Uno de sus mayores exponentes, Francisco de Vitoria, sostuvo que por derecho natural todos los hombres eran libres y dueños de sus cosas, incluidos los infieles, a los que no se podía privar de su dominio por ser pecadores o criaturas irracionales (García, 2012). Recuperando la tradición tomista, otros integrantes de esta escuela, como Luis de Molina, Domingo de Soto, Bartolomé de las Casas y Vázquez de Menchaca, reconocieron el derecho al dominio público y particular de los pueblos no cristianos, negando que sus territorios pudiesen considerarse res nullius y ser objeto de apropiación (Agüero, 2012).

En la práctica, sin embargo, el dominio indígena implicaba un complejo entramado de derechos sobre la tierra, con diversas posibilidades de posesión y formas de explotación, que en el virreinato del Perú combinaba las tierras del Tawantinsuyu, de los soberanos, de las divinidades, las explotaciones comunales, las parcelas para el sostenimiento de linajes distinguidos y de unidades domésticas, entre otras, entreveradas a lo largo del territorio. Sobre ellas se precipitaron los españoles, logrando ocupaciones de hecho, ventas forzadas o por un pago mínimo, en combinación con la concesión real de tierras baldías sobre las cuales la doctrina jurídica afirmó el dominio regio. Si en Nueva España se consideraron baldíos pertenecientes a la corona las tierras del soberano Moctezuma, las del culto y las conquistadas por los mexicas fuera de Tenochtitlan (Menegus, 1991), en el virreinato del Perú los derechos de sucesión del monarca castellano a las tierras del Inca y de las divinidades promovidas desde el Cusco por derecho de conquista provocaron controversias. De acuerdo con Assadourian (1994), en los momentos previos a 1571 las opiniones que sostuvieron el derecho de sucesión del monarca a las tierras del Inca y de los cultos cusqueños se contrapusieron tanto a la práctica concreta de los españoles, quienes se arrogaron el derecho de tomar para sí esas tierras, como a la postura de devolver a los pueblos indígenas las tierras que el Tawantinsuyu les había tomado por la fuerza para su propio uso.

Preocupado por afianzar la colonización, en 1541 el rey Carlos I ordenó por provisión que se pregonara en la ciudad de Los Reyes que los pastos, montes y aguas del virreinato del Perú fueran comunes "para que todos los vezinos della, assi los que agora ay como los que de aquí adelante oviere puedan gozar dellos libremente y ansimismo puedan hazer y hagan cabe[n] qualesquier boyos que oviere en la dicha provincia, cavañas y traer sus ganados" (Encinas, 1945, I, ff. 64-65).

Este impulso de uso común de montes, pastos y aguas en la jurisdicción virreinal -al que se puede adicionar la voluntad regia en el caso de la cercana gobernación de Cartagena de uso común de tierras particulares luego de levantado el fruto, como se ordenó en 1543 (Encinas, 1945)-, sumó en 1554 el interés de la corona por conocer la modalidad de uso de los pastos de acuerdo con las costumbres prehispánicas en Perú (Encinas, 1945).

Una década más tarde, por real cédula de 1568, se ordenó en los virreinatos el reparto de tierras baldías a los españoles e indios para su labranza, así como a los concejos para propios, ejidos y otros aprovechamientos. En su disposición, Felipe II brindó una inicial definición de las tierras baldías para los contextos ultramarinos, sosteniendo que "Los baldíos, suelo y tierra de las Indias que no estuviesen concedidos particularmente por Nos o nuestros antecesores, a lugares o personas particulares, es nuestro cargo y de nuestra Corona real y podemos de ello disponer a nuestro arbitrio y voluntad" (Solano, 1991, p. 209).

En ese sentido, los baldíos americanos se definían como tierra no concedida por la corona -nada se decía sobre su explotación productiva- y, por lo tanto, tierra sujeta a la real voluntad. Se ha propuesto que esta disposición expresó la preocupación propia de la década de 1560 de las esferas regia y vicerregia novohispana por la definición de la figura jurídica de los baldíos, motivada 
por la extensión de las tierras desocupadas por la despoblación de los territorios indígenas en el virreinato de Nueva España (Menegus, 1991). En cambio, al menos la correspondencia de los virreyes del Perú, recopilada por Roberto Levillier (1924) para la misma década, no refleja un interés particular de la administración virreinal sobre los baldíos. Fue en la década siguiente, quizá frente al arribo de la real cédula de 1568, que el virrey don Francisco de Toledo (1569-1581) manifestó su incertidumbre por disposiciones regias que se contraponían a aquellas anteriores que disponían la explotación de "los montes pastos y baldios altos y bajos en común a toda esta tierra" (Levillier, 1924, IV, p. 424). En ese sentido, el desconcierto del virrey señalaba la continuidad de prácticas, por lo menos hasta la década de 1570, de uso común de los baldíos, por lo cual el virrey se manifestaba perplejo ante la posibilidad de otorgarlos a particulares en el marco de un reforzamiento del derecho regio sobre los mismos.

El uso común y el reparto gracioso de las tierras estuvieron presentes en las ordenanzas de descubrimiento y nueva población de 1573, mediante las cuales la corona intentó estructurar jurídicamente la fundación de nuevas poblaciones y el reparto de solares, con la definición de medidas de extensión y distancias entre núcleos urbanos y rurales. Asimismo, se preveía el diseño de ejidos - para el recreo de la población y el ganado de las ciudades-, dehesas -para los bueyes, caballos y ganado de carnicería-, y propios para el concejo; y se determinaba que los pastos fueran de uso común, alzados los frutos, exceptuando la dehesa boyal y concejil (Ots, 1959). Finalmente, las ordenanzas reservaban tierras realengas, al disponer que, tras el reparto de tierras de labor y regadío, las "demas queden para Nos, para que hagamos merced a los que despues fueren a poblar" (Ots, 1959, p. 22).

A fines del año 1581, Felipe II volvió a centrar su atención en el valor fiscal de las tierras baldías del virreinato peruano, enviando cédula al virrey don Martín Enríquez (1581-1583) debido a los "muchos pretendientes que las querian para el pasto de sus ganados y quien[es] compren otras de estas tierras baldias que estan por repartir" (Encinas, 1945, I, f. 74). Por ello, solicitaba el envío de una relación que precisara:

la cantidad de las dichas tierras baldias que ay en essos reynos y en que partes y para que efecto de los arriba dichos [dehesas, pastos de ganado] seria mas a proposito y que balor tendrian y el aprovechamiento que de los arrendamientos de las dichas deessas, aviendose de hazer, y de la venta de las dichas tierras baldias que estan por repartir se seguiria y si de hazerse lo susodicho resultaria algun inconveniente o se causaria escandolo (Encinas, 1945, I, f. 74).

La disposición deja entrever una cierta imprecisión en el significado del término tierras baldías como aquellas que estaban sin un uso específico y como aquellas no concedidas. Frente a ella, el virrey don Martín Enríquez aconsejó que, dado el escaso ingreso monetario que representaría la venta de baldíos en la jurisdicción, sería mejor que se continuara con su reparto gracioso. Incluso, advertía que desde la perspectiva de los pobladores el dominio regio sobre los baldíos no estaba asentado. En ese sentido, resulta sugestivo que en su correspondencia del 6 de agosto de 1582 el virrey vinculara la venta de tierras baldías con las poblaciones indígenas, al precisar: "Aquí no hallo tan favorecido y asentado que todos los valdios son de la real corona porque en esta parte a los yndios se les a dado mas mano que en la Nueva España y asi ellos son los que han bendido muchos pedazos de tierra” (Levillier, 1924, Ix, p. 101). 
En este contexto de uso común y referente disputado de las tierras, arribaron al virreinato del Perú las reales cédulas emitidas por Felipe II el 1 de noviembre de 1591 en El Pardo. Como señaló Ots (1959), estas disposiciones implicaron una novedad: si hasta entonces ni la corona ni los oficiales regios consideraban con firmeza que el rey pudiera o debiera percibir un rendimiento fiscal por su regalía sobre las tierras, a partir de las cédulas de 1591 las tierras realengas no concedidas pasaron a considerarse un ramo más de la Real Hacienda. Las disposiciones ordenaban el examen de los títulos de la tierra en manos hispano-criollas, su medición a fin de hallar ocupaciones de hecho ("demasías") sobre tierras realengas, de los consejos, de particulares y/o de los pueblos indígenas, el concierto del canon monetario por composición de acuerdo con la irregularidad, la estructuración de espacios comunes para los núcleos urbanos y la inspección de las tierras de los repartimientos de indios para garantizar las necesarias para su reproducción contemporánea y futura (Solano, 1976). En ese sentido, con el propósito de remediar el desorden en la distribución de los baldíos, así como las ocupaciones de hecho, las reales cédulas se focalizaron en la posesión hispano-criolla de la tierra con títulos defectuosos o sin título alguno, explotadas o no, y que, hasta concertar la composición, seguían siendo patrimonio de la corona.

Sin constituirse en su objeto central, el término tierras baldías surcó el texto de las cuatro reales cédulas de 1591 y lo hizo con más de un significado. Podría señalarse que de modo predominante se reiteró la semántica contenida en la real cédula de 1568, definiéndose los baldíos como los "suelos y tierras que no estuvieren concedidos", o como las "tierras que [...] nunca han sido dadas ni repartidas", como se define en la segunda cédula (Recopilación, libro Iv, título II, ley xIv, 1996). Este significado reiterado en las disposiciones regias para los virreinatos americanos igualaba las tierras baldías a aquellas no concedidas y que, en caso de haber sido ocupadas sin "verdadero título", debían restituirse al dominio real. A este primer significado se adicionaba otro, presente en el contexto peninsular, según el cual el término baldíos designaba las tierras de uso común vinculadas a los concejos urbanos. Así, en la primera cédula se ordenaba al virrey que reservara lo "necesario para plazas y ejidos, propios pastos y baldios de los lugares y concejos que estan poblados" (Solano, 1991, p. 270).

Aún puede distinguirse una tercera definición que asimilaba las tierras baldías a aquellas sin poblar ni cultivar - resultante quizá de la polisemia peninsular del término durante el siglo XVI. En ese sentido, la tercera cédula de 1591 señalaba que "las tierras que no [h]an sido ocupadas ni repartidas [...] las podais dar e conçeder de nuebo" (Jurado, 2014a, p. 11). Esta confusa sinonimia entre tierras sin un uso específico - no ocupadas- y tierras no concedidas también podía observarse en la primera real cédula que ordenaba que las "tierras que, asimismo, hubiere por ocupar, que nunca han sido dadas ni repartidas”, se podrían conceder (Solano, 1991, p. 271).

Finalmente, las disposiciones contenían una definición adicional acerca de un rango de tierras capaces de ser concedidas a particulares en beneficio de la corona y que constituían un tipo de tierras residuales, obtenidas tras el reordenamiento de la territorialidad urbana e indígena. En ese sentido, la segunda real cédula de 1591 ordenaba que, una vez que se reservaran las tierras necesarias para la reproducción contemporánea y/o futura de los núcleos urbanos y de los repartimientos de indios, "toda la demás tierra quede y esté libre y desembarazada para hacer merced y disponer de ella a mi voluntad” (Recopilación, libro Iv, título II, ley XIv, 1996). En el mismo sentido, la tercera real cédula era aún más imprecisa al sostener que, luego de reservar lo mencionado más arriba, "todo lo demás lo podéis componer" en beneficio de la Real Hacienda (Jurado, 2014a, p. 11). Se ha señalado que estas expresiones revelan que la protección monárquica de los derechos de los indios a la conservación de sus tierras mediante las reales cédulas de 1591 era aparente, pues ellas 
legitimaban la capacidad del monarca a decidir, por ejemplo, sobre el destino de las tierras indígenas desocupadas por las congregaciones de indios en el virreinato novohispano (Carrera, 2015). Para el virreinato del Perú, lo anterior merece una discusión más profunda de cara al accionar del virrey don García Hurtado de Mendoza y su entorno.

En cuanto al dominio útil de vecinos y pobladores hispano-criollos sobre tierra realenga no concedida, se señaló más arriba que había estado presente en las discusiones del Consejo al momento de la venta de baldíos en la península. La problemática no estuvo ausente en las reales cédulas de 1591 y su contenido reforzó la idea de confirmar a los poseedores en su posesión. Así, por ejemplo, era voluntad regia que, si los ocupantes quisieran componerse en sus demasías, el virrey y sus oficiales deberían "proceder en todo con animo de formar y legitimar la posesion en que hallaredes a cada uno mediante la dicha composición" (Solano, 1991, p. 271). En el virreinato del Perú correspondió al virrey don García Hurtado de Mendoza disponer su ejecución, nombrando e instruyendo jueces de comisión en jurisdicciones diversas. El término tierras baldías no estuvo ausente en sus instrucciones, caracterizadas asimismo por la falta de precisión semántica del mismo. Así, la comisión redactada en agosto de 1592 para el primer juez del distrito de Charcas fray Luis López, obispo de Quito, detallaba que "fuese vendiendo todo lo baldio en aquellas provinçias y que las personas que quisiesen conponerse en aquello que poseyesen tomase compusiçion con ellas" (Jurado, 2014a, p. 12). Tampoco las instrucciones otorgadas al juez de comisión de la jurisdicción de Cusco y Arequipa, licenciado Alonso Maldonado de Torres, en septiembre de 1593 contuvieron mayores precisiones. ${ }^{1}$ En ellas se limitó a solicitar al juez la elaboración de una relación con las tierras inspeccionadas, en la cual "si fueren baldios se porna como lo son". ${ }^{2}$ Sin embargo, la ejecución en el terreno llevó a distintos jueces de comisión a demandar mayores precisiones al virrey, quien decidió convocar en noviembre de 1593 a reconocidos oficiales para tratar semanalmente, en su presencia, las dudas surgidas en lo local (Glave 2014). En este contexto, influyentes personalidades emitieron interpretaciones de las disposiciones regias que discutieron la procedencia material de las tierras que conformarían las tierras baldías en el territorio virreinal peruano.

\section{Interpretaciones locales: Alberto de Acuña y Pedro MuñIZ ante las Reales cédulas de 1591}

El virrey don García Hurtado de Mendoza convocó a las juntas semanales a su asesor licenciado Rengifo, al abogado general de los indios Alberto de Acuña, al secretario de gobernación Álvaro Ruiz de Navamuel, al canónigo de la catedral de Lima, doctor Molina, y al franciscano Alonso de Valdivieso (Glave, 2014). Al menos dos reflexiones escritas llegaron a manos del virrey y, entre muchos otros ítems, matizaron el rango de tierras que podía dar referente material al concepto jurídico de baldíos contenido en las reales cédulas de 1591 .

Una de ellas fue elaborada en 1594 por el doctor Pedro Muñiz, deán de la iglesia catedral de Lima y vicario general de la diócesis, quien respondía la enumeración de las dudas surgidas en el terreno y sistematizadas a solicitud del virrey. El deán abordó la problemática de las tierras no

${ }^{1}$ Alonso Maldonado de Torres era oidor de la real audiencia de Lima y fue nombrado juez de comisión el 10 de septiembre de 1593 para los distritos de Cañete, Chincha, Pisco, Sarcomana, Arequipa, Cusco y sus corregimientos y la provincia de Vilcabamba.

${ }^{2}$ Comisión al licenciado Maldonado de Torres, oydor de la audiencia sobre lo tocante a composiciones de tierras y las instrucciones. Lima, 273, f. 69v. Archivo General de Indias (en adelante AGI). 
concedidas, uno de los significados de baldíos contenidos en las reales cédulas de 1591. En particular, su escrito reflexionó sobre aquellas que, con títulos defectuosos o sin título alguno, estaban en posesión hispano-criolla, aspecto nodal de las disposiciones regias y de las cuales se aspiraba a extraer ingresos para la Real Hacienda. Apelando a la tradición jurídica, Muñiz sostenía que "en derechos y theulugia es tambien titulo bueno que conçede propiedad la prescripçion, que es posesion de tiempo con buena fe". ${ }^{3}$ El deán introducía así el problema del dominio útil de buena fe como factor que transmutaba la posesión de los baldíos, en tanto tierras no concedidas, en dominio particular, al limitar o prescribir el dominio eminente del rey sobre los mismos, aunque sin atreverse a cuantificar el número de años necesarios para la prescripción. Un cuestionamiento similar al derecho de vender tierras en posesión particular había realizado dos décadas antes uno de los jueces encargados de la venta de baldíos en la provincia de Toledo (España), en 1574. De acuerdo con Vassberg (1983), el juez Juan de la Concha manifestaba tener "gran escrúpulo de conciencia” al vender ciertas tierras que durante mucho tiempo habían sido tratadas como dominio particular, aunque su comisión sostuviera que fueran baldías (p. 225).

La prescripción de dominio seguiría siendo objeto de debate jurídico y el deán Muñiz había señalado uno de sus problemas nodales, esto es, la temporalidad de la posesión de buena fe que la transmutaba en dominio pleno. Cincuenta años más tarde, la real cédula del 10 de junio de 1646 abordaría lo anterior al disponer que, para que un poblador pudiera componer las demasías, era necesario que hubiera poseído la tierra por diez años, pues "aunque alegue que las esta poseyendo [...] este pretexto solo no ha de ser bastante" (Recopilación, libro IV, título xII, ley XIx, 1996). Dos años más tarde, y fundamentándose en la misma disposición, Solórzano (1972) reforzaría el dominio regio al señalar que sólo tras 40 años de posesión y labranza de tierras baldías sería acertado disimular y no solicitar a los pobladores sus títulos.

Asimismo, Muñiz reflexionó sobre aquella categoría residual de tierras presente en las reales cédulas de 1591, la cual incluía las tierras consideradas excedentarias para la reproducción social contemporánea o futura de los consejos y de las comunidades indígenas. Para ello, se sirvió del accionar concreto informado por los jueces comisionados Alonso Maldonado de Torres y fray Domingo de Valderrama ${ }^{4}$ y de su propia experiencia como arcediano del Cusco. El deán sostenía que no era voluntad del rey quitar tierras a las comunidades indígenas y que, en ese sentido, debían restituirse las tierras que Valderrama les había "vendido por vacas [pues] las poseían actualmente los yndios y las labravan y an labrado hasta aquí por suyas". ${ }^{5}$ Muñiz advertía al virrey que el mismo accionar se repetiría en Cusco cuando el juez Maldonado de Torres declarara excedentarias las tierras que los indios labraban "por si y en companias que hazen con españoles" para el pago de sus tasas. ${ }^{6}$ En el vocabulario de la época, vaca participaba de la definición de vacante, al referir a una prebenda o dignidad "vaca por muerte, promocion o dejacion del que la tenia" (Covarrubias, 1943, f. 61v). El mismo sentido conservó el término con posterioridad, al definirse vaco como la cualidad del empleo, dignidad o puesto "que esta sin sujeto que lo ocupe" (Real Academia Española, 1726-1739). De acuerdo con Muñiz, se habían vendido por vacas tierras labradas, ocupadas y de dominio indígena, pero, al ser consideradas excedentarias por el juez de comisión, se habían

${ }^{3}$ Copia de las dudas que dio por memoria el doctor Muñiz. Patronato, 191, ramo 3, f. 2v. AGI.

${ }^{4}$ Fray Domingo de Valderrama fue nombrado juez de comisión el 9 de septiembre de 1593, para los distritos de Arnedo, Guaurala, Varanca, Pativilca, Parmonga, villa de Santa y su corregimiento, ciudad de Trujillo, Villa de Saña y ciudad de Piura.

${ }^{5}$ Copia de las dudas que dio por memoria el doctor Muñiz. Patronato, 191, ramo 3, f. 2r. AGI.

${ }^{6}$ Copia de las dudas que dio por memoria el doctor Muñiz. Patronato, 191, ramo 3, f. 2r. AGI. 
subastado en beneficio de su majestad cual si fueran realengas. Este párrafo tan sustancioso de su reflexión cuestionaba uno de los rubros de tierras que más se vería afectado en el proceso de ejecución de las reales cédulas de 1591 en el distrito charqueño: las tierras indígenas consideradas innecesarias para su reproducción social y sobre los cuales los jueces comisionados reclamaban derechos regios.

Una segunda interpretación de las reales cédulas de 1591 fue elaborada por el doctor Alberto de Acuña, abogado general de los indios del virreinato por nombramiento del virrey conde del Villar y de don García Hurtado de Mendoza. Su profundo conocimiento de las demandas y las prácticas posesorias indígenas e hispano-criollas a partir de la lectura de los procesos judiciales que los líderes indígenas dirimían en Lima otorga a sus escritos un valor adicional. En esta oportunidad, Acuña afirmaba que la monarquía presuponía la existencia de cuatro maneras de tierras en los virreinatos americanos: $a$ ) las que los españoles tenían con justo título y el rey las mandaba dejar; b) las que los españoles poseían sin justos títulos y el rey promovía su composición o restitución a la corona; $c$ ) las tierras que tenían los indios y se las mandaba dejar; $d$ ) los baldíos. Sobre ellos, y retomando la oscilación semántica como tierras sin uso específico y tierras sin concederse, Acuña meditaba que para el rey los baldíos referían a "tierras que no [h] an sido ocupadas ni repartidas, luego [el rey] no tiene por baldias las que [h]an ocupado los yndios". 7 En este sentido, se puede afirmar que la interpretación coincidía con aquella del deán de Lima, don Pedro Muñiz. Sin embargo, de acuerdo con Acuña, era el exceso realizado por los españoles lo que el rey pretendía remediar con las disposiciones de 1591, quitándoles las tierras que tuvieren con títulos "injustos" para que fueran restituidas a la corona. Sintetizaba el letrado: "de manera que las que manda dar a los yndios [en caso de faltarles] es de las que se quitaren a los españoles y no de las que ellos tienen, las quales les manda confirmar".

A pesar del desarrollo de las reuniones semanales y de la lectura de los pareceres reseñados más arriba, al redactar en octubre de 1594 su comisión e instrucción para el segundo juez del distrito de Charcas, don Pedro Osores de Ulloa, el virrey Hurtado de Mendoza no aportó claridad (Jurado, 2014a). Si Muñiz y Acuña presentaron dudas acerca del rango de tierras pasibles de ser concedidas en beneficio de la Real Hacienda, la instrucción vicerregia indicaba al oficial que: "Lo que fuere baldio y perteneçiere a Su Magestad lo haveis de vender en publica almoneda y rematarlo en quien mas diere por ello". Asimismo, incorporaba a la comisión el texto de la tercera real cédula de 1591, en la cual se definían los baldíos como tierras no ocupadas ni repartidas y en la que se utilizaba la frase más imprecisa para habilitar la composición de "todo lo demás", tras reservar lo necesario para la reproducción social de los núcleos urbanos y de las comunidades indígenas.

\section{LAS TIERRAS BALDÍAS EN LA PRIMERA COMPOSICIÓN EN CHARCAS: EN TORNO A LA PRAXIS JUDICIAL DE DON PEDRo OsORES de UlLOA (1594-1597)}

La comisión del general don Pedro Osores de Ulloa como juez de composición y venta de tierras delimitaba su espacio jurisdiccional a la ciudad de La Plata, asiento de Porco, Potosí, Cochabamba y los corregimientos de Mizque, Pocona, Chayanta, Yamparaes, villa de Tomina y Tarija (Jurado, 2014a). De la enumeración puede observarse que su oficio tocaba a un distrito central del

\footnotetext{
${ }^{7}$ Copia de las dudas que dio por memoria el doctor Alberto de Acuña. Patronato, 191, ramo 4, f. 1r. AGI.

${ }^{8}$ Copia de las dudas que dio por memoria el doctor Alberto de Acuña. Patronato, 191, ramo 4, f. 1r. AGI.

${ }^{9}$ Instrucción a don Pedro Osores de Ulloa de lo que a de guardar en la visita de las tierras, 1594. Patronato, 191, ramo 14, núm. 2, f. 1r. AGI.
} 
virreinato del Perú, por la presencia de la real audiencia en la ciudad de La Plata, por su densidad demográfica, por la producción de plata en torno al Cerro Rico de Potosí y por la demanda mercantil de sus diversos distritos urbanos y mineros. Asimismo, sus espacios agrarios presentaban una marcada heterogeneidad, con regiones de fuerte presencia de dominio colectivo indígena, como en el corregimiento de Chayanta, y zonas de más reciente presencia hispano-criolla, aunque de importante avance de dominio particular de la tierra, como la región cochabambina.

A la llegada de Osores de Ulloa, la jurisdicción aún presentaba huellas del dominio ejercido por el Tawantinsuyu seis décadas atrás. Con su conquista, los incas habían confirmado el patrón de asentamiento entreverado y de aprovechamiento altitudinal del paisaje de las poblaciones indígenas, aunque amojonaron sus territorios y tomaron tierras destinadas a su propio sostén y al del culto, como al de distintos linajes privilegiados. En algunas regiones se apropiaron de tierras cultivadas y no cultivadas, en las cuales se implementó el riego o la construcción de andenería para ponerlas en producción o ampliar la superficie cultivada. Así, el valle de Cochabamba fue repoblado en función de la producción de maíz para las necesidades del Tawantinsuyu; también en los yungas de Pocona y Totora se establecieron chacras para el cultivo de coca con fines incaicos (Schramm, 2012; Wachtel 1980). Entre otras regiones, Tapacarí -en el corregimiento de Cochabamba- y el valle de Sucusuma - en el corregimiento de Chayanta- fueron apropiados para atender las necesidades agrícolas y artesanales cusqueñas, mientras que los valles mesotérmicos del territorio yampara fueron reconfigurados poblacionalmente a semejanza del valle bajo cochabambino, según propósitos incaicos (Assadourian 1994; Platt et al., 2006; Presta, 2013; Río, 2005). En el siglo Xvi los cronistas recogieron el término moya para referir a dimensiones topográficas, económicas y ecológicas de ciertos espacios reservados como pastizales para los recursos ganaderos destinados al culto y al Tawantinsuyu (Murra, 1978), o como cotos de caza y espacios de recreo del soberano (Niles, 1987-1989). De acuerdo con fray Martín de Murúa, los inspectores incaicos delimitaban periódicamente los mojones que señalaban las tierras reservadas, donde no se podía ingresar para cazar, pescar, cortar madera y/o extraer metales o sal (Murra, 1978). También el Tawantinsuyu se apropió de sitios para la construcción de fortalezas en la región, como el complejo religioso-militar y económico fronterizo del eje Pocona-Totora-Mizque y los valles orientales de Tarija con el propósito de defender y obtener recursos de los valles cálidos y selvas aledañas (Oliveto, 2011; Schramm, 2012).

Con la conquista castellana de Charcas, en 1538; el descenso demográfico indígena, la fundación de ciudades como La Plata, en 1540; Cochabamba en 1571 y Tarija en 1574; la explotación de las minas de Porco en 1540 y Potosí en 1545, y la apropiación hispano-criolla de tierras trastocaron la posesión, la extensión y las formas de explotación del espacio agrario (Assadourian, 2005; Barnadas, 1973). Numerosos indígenas volvieron a sus regiones de origen, mientras avanzaba el descenso poblacional, la mercedación de tierras, su venta forzada y a valores mínimos y la ocupación de hecho. En este contexto, en enero de 1569 el rey instruyó a la real audiencia de Charcas proveer lo conveniente para "repoblar por españoles, que esten sin ocupacion, las tierras vacias de indios por las alteraciones pasadas”. Así, la monarquía establecía un sólido antecedente en la sociedad charqueña al vincular en la administración de justicia las tierras sin ocupación evidente y bajo dominio de una demográficamente decreciente población indígena, y el derecho regio a disponer de su destino (Libros, Registros-Cedularios de Charcas, 1992, i, p. 53).

Asimismo, entre los años 1572-1575, bajo el gobierno del virrey don Francisco de Toledo, la región experimentó de modo desigual la concentración forzada de la población indígena dispersa a pueblos de reducción o pueblos de indios. El traslado provocó efectos complejos en las 
sociedades indígenas: desde usos parciales de los pueblos de reducción y el retorno a los viejos asentamientos, la fundación de nuevas aldeas y estancias, hasta la transformación de los modos de tenencia doméstica y supradoméstica de la tierra y del ejercicio de la verticalidad ecológica (Platt et al, 2006; Río, 2005; Saignes, 1992). De modo simultáneo, y pese a que las disposiciones regias estipularon que las poblaciones trasladadas conservaran sus derechos sobre los lugares abandonados, capitulares y oficiales regios mercedaron fracciones de esas tierras, bajo el pretexto de estar alejadas, incultas o no ser de provecho para los grupos indígenas, como puede constatarse en el corregimiento de Chayanta, Mizque y Pocona, entre otras (Assadourian, 2005; Jurado, 2014b; Schramm, 2012). Pese a ello, existe consenso historiográfico en señalar una mayor presencia de dominio particular hispano-criollo de las tierras en zonas vallunas, como Cochabamba, donde el equilibrio entre comunidad y hacienda se habría inclinado a favor de esta última, en relación con corregimientos de altura, como el de Chayanta, donde el dominio indígena se sostuvo a lo largo del tiempo (Larson, 1992; Platt, 1982).

Apenas dos décadas más tarde, el virrey don García Hurtado de Mendoza inició la ejecución de las disposiciones de 1591 por el distrito de Charcas. Lo anterior se produjo con ciertas dosis de conflictividad y resistencia, determinando el accionar sucesivo de dos jueces comisionados: fray Luis López, obispo de Quito, primero, y el general don Pedro Osores de Ulloa, más tarde. El análisis del accionar de fray Luis López como juez de composición forma parte de una investigación aún en curso; sin embargo, se puede señalar que el modo de conceptuar las tierras que conformarían los baldíos ocupó un lugar importante en el desempeño de su oficio. En ese sentido, en su correspondencia del año 1593, el obispo utilizó el término baldío para designar, por un lado, las tierras tomadas a los chiriguanos, población indígena no sujeta al dominio efectivo de la corona y, por el otro, las tierras que él consideraba excedentarias para la reproducción social indígena. De este modo, el obispo informaba al virrey que "adjudiqué yo a los yndios las tales tierras que les son necesarias y las demás [ordené que] se publiquen por baldías para poder disponer dellas". ${ }^{10} \mathrm{Te}-$ niendo en cuenta este antecedente y a fin de evaluar el componente y destino de las tierras baldías en la jurisdicción, se propone a continuación un análisis de la práctica judicial llevada adelante en el terreno por Osores de Ulloa, entre octubre de 1594 y abril de 1597, dada la profusa casuística contenida en el registro documental.

Perteneciente al linaje de los condes de Monterrey, don Pedro nació en 1554 en Portillo (Valladolid). De acuerdo con Vassberg (1983), Valladolid se encontraba entre las seis provincias de la península que más ingresos habían generado a la Real Hacienda por venta de baldíos entre los años 1560-1590. Asimismo, de la audiencia de Valladolid provino el juez que llevó adelante la primera inspección de las ocupaciones de tierras comunales en el reino de Granada en 1560 (Vassberg, 1983). En ese sentido, si bien Osores de Ulloa se ausentó de su tierra natal para servir en las guerras de Italia, Malta y Túnez, su educación se produjo en el contexto de inspección regia de los baldíos vallisoletanos. En 1584, don Pedro pasó al virreinato del Perú con nombramiento de corregidor de la ciudad de La Plata y Potosí, oficio que desempeñó por seis años a partir de $1587 .{ }^{11}$ Vecino potosino, Osores de Ulloa se convirtió en dueño de un ingenio de minas y en 1594 recibió el nombramiento de juez de comisión para aplicar en Charcas, junto a otras normativas, las reales cédulas de 1591 (Jurado, 2014a). En ese sentido, podría afirmarse que Osores de Ulloa formó

${ }^{10}$ De lo que escrivio a Su Señoria el maestro don fray Luis López, obispo electo de Quito, en razon de las compusiciones de tierras como juez comisario dellas. Lima, 273, f. 78v. AGI.

${ }^{11}$ Información de oficio y parte: Pedro Ozores de Ulloa. Lima, 215, ramo 4, f. 2r. Agi; Actas del Cabildo de Potosí, núm. 5, f. 339v. Archivo y Biblioteca Nacional de Bolivia. 
parte del grupo de oficiales que, a lo largo del dominio castellano, ejerció la justicia unipersonal en un espacio jurisdiccional delimitado, sin formación formal en derecho, aunque con vasta y desigual experiencia acumulada relativa tanto a las nociones y usos del derecho como a la práctica de judicialización de la vida cotidiana (Albornoz, 2015).

Con el objeto de lograr una aproximación a su administración de justicia durante la composición y venta de tierras, se toma su juicio de residencia -realizado por el oidor Juan Fernández de Recalde en el año 1600- como principal corpus documental, al contener una profusa casuística de las prácticas posesorias en contextos agrarios de finales del siglo XVI. ${ }^{12} \mathrm{El}$ expediente incluye, entre otras piezas legales, el detalle de las quince imputaciones relativas a su oficio, con la nómina de testigos que las fundaban, seguido por los descargos redactados por Osores de Ulloa y su asesor legal, tendentes a explicar las situaciones denunciadas en cada cargo. Tras su lectura se puede identificar un total de 28 casos empíricos relativos a tierras cuyo dominio seguía siendo disputado en el año 1600 (véase cuadro 1). La muestra es pequeña en comparación con el número total de casos que debió inspeccionarse durante la administración de justicia de dos jueces de comisión, en un distrito extenso y durante un marco temporal amplio [1592-1597]. Sin embargo, dada la ausencia de un fondo archivístico específico para las composiciones de tierras de la región charqueña, se realiza el análisis en tanto muestreo basado en los sujetos disponibles en la documentación, asumiendo el carácter propositivo e inicial de las observaciones.

De sus investigaciones sobre el pueblo de Sumaro (actual Perú), Donato Amado (1998) concluía que la primera composición había servido para reducir los antiguos derechos indígenas a sus tierras, originando las haciendas de la región. Así, los jueces comisionados habían concentrado el dominio colectivo indígena alrededor de sus pueblos de reducción, dejando grandes extensiones para ser sometidas a composición con los vecinos hispano-criollos en beneficio de la Real Hacienda. A las mismas conclusiones llegaron investigaciones posteriores sobre el mismo proceso del siglo Xvi en el distrito de Charcas (Glave, 2009; Jurado, 2014b; Palomeque, 2010; Platt et al., 2006; Río, 2005). En ese sentido, si las tierras colectivas indígenas fueron afectadas y vendidas o compuestas como tierras realengas, el problema entonces toca de lleno a la definición del rango de tierras que podían ser concedidas a los poseedores mediante el pago por composición, o bien, de ser restituidas o adjudicadas a la corona y (re)asignadas a través de su venta en pública almoneda.

${ }^{12}$ Información de oficio y parte: Pedro Ozores de Ulloa. Lima, 215, ramo 4. AGI. 


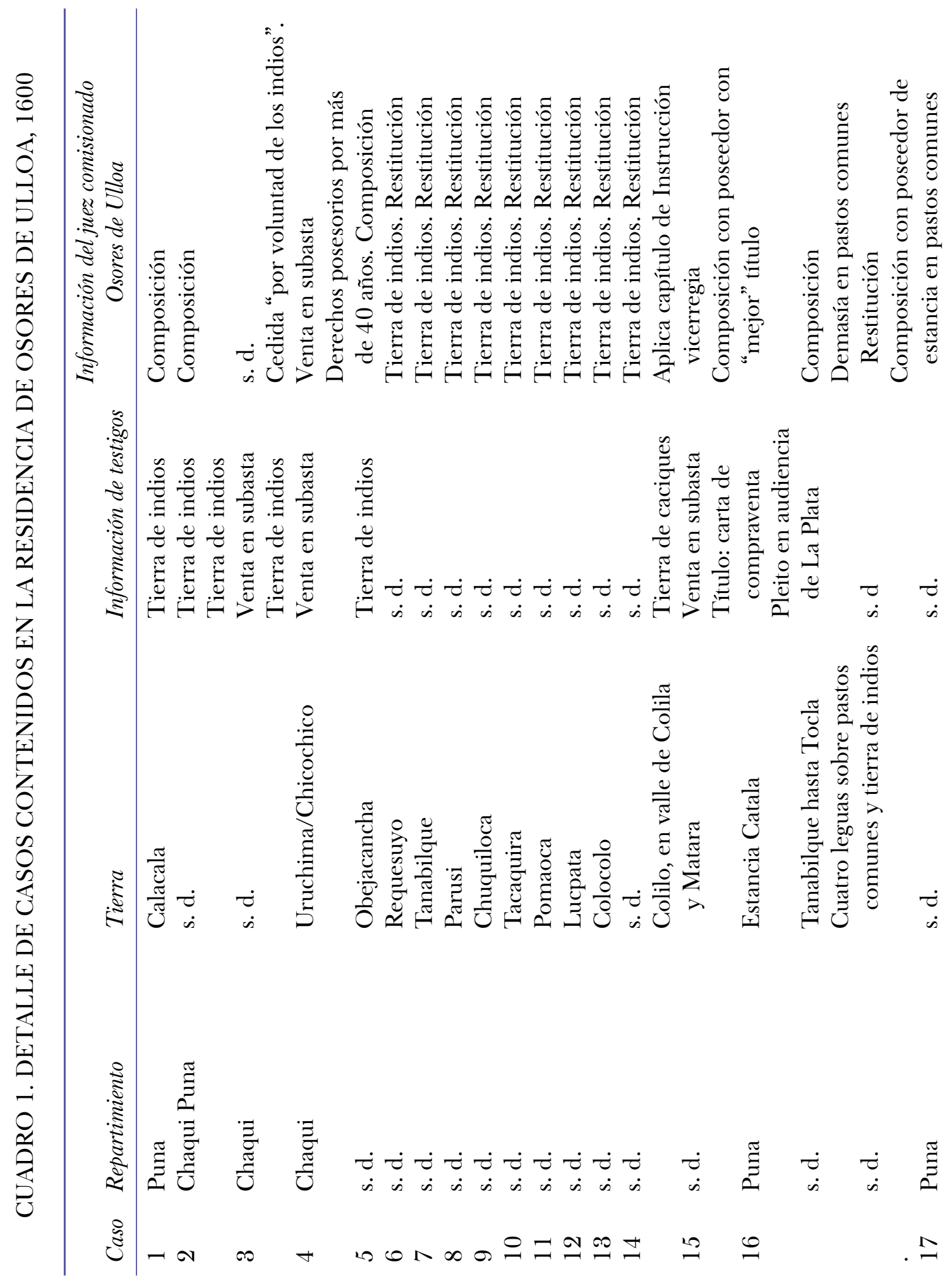



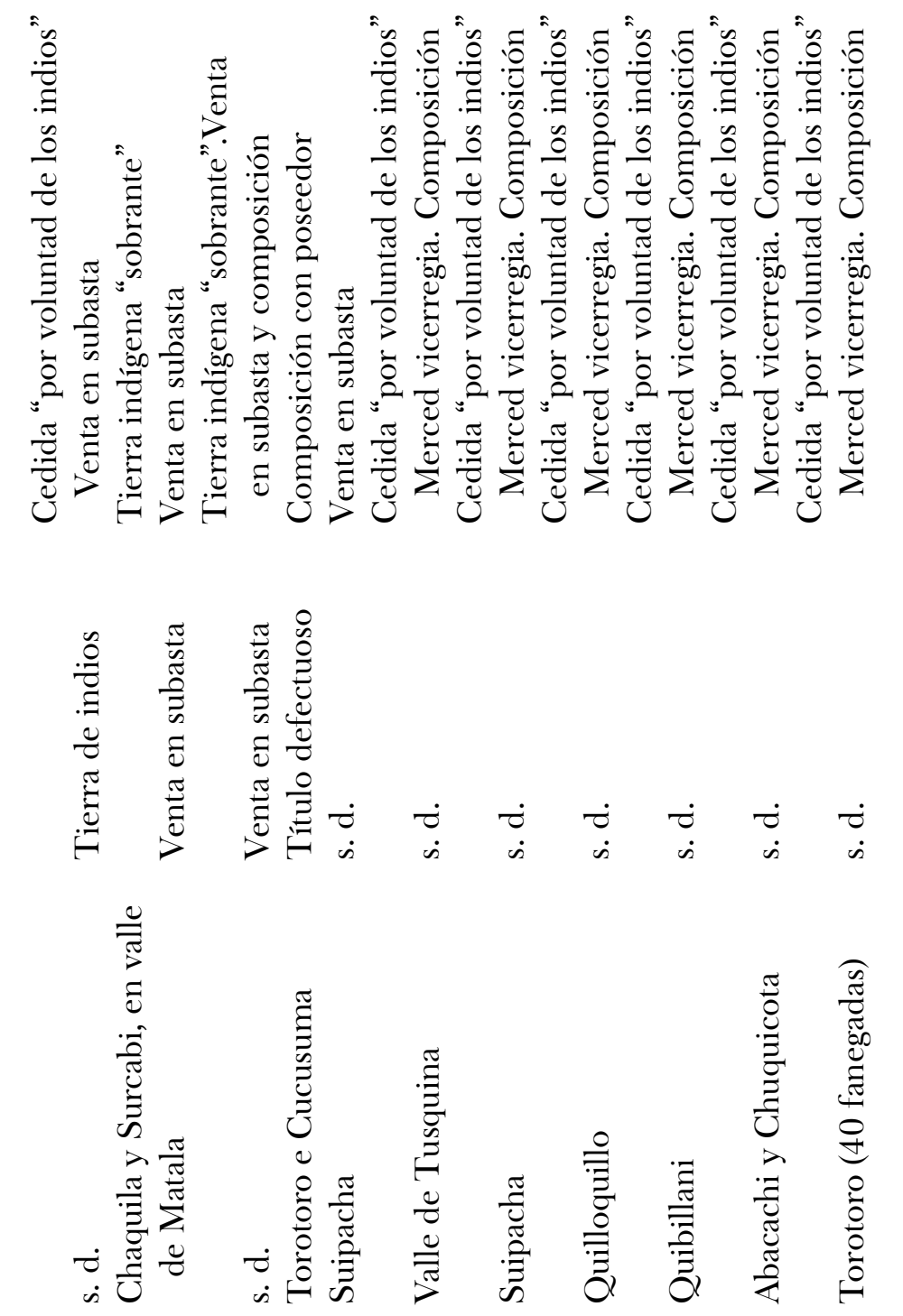

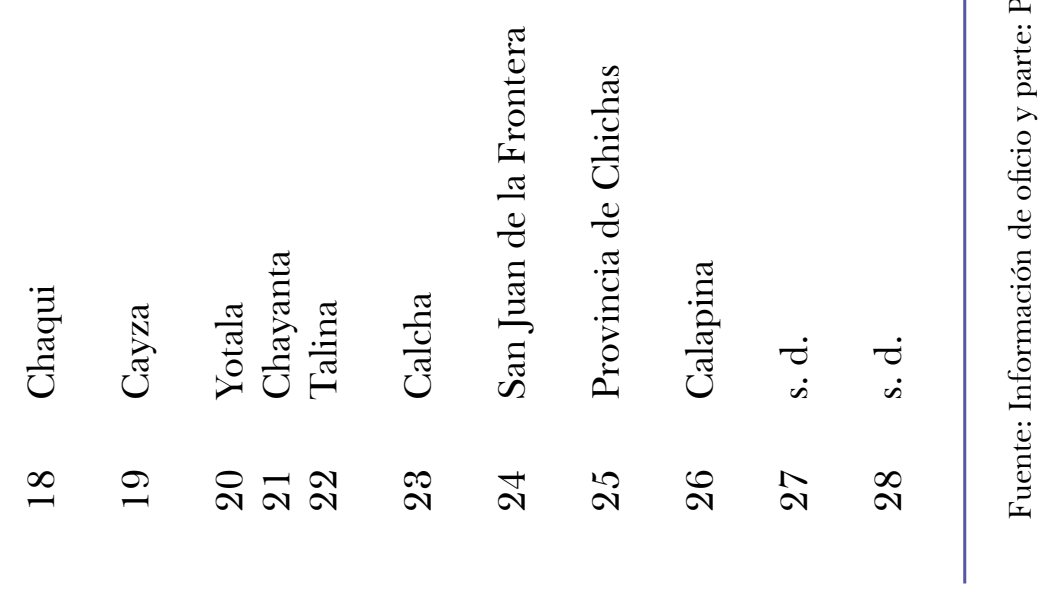


CUADRO 2. TIERRAS VACAS SEGÚN VECINOS CHARQUEÑOS, 1600

\begin{tabular}{|c|c|c|}
\hline Definición de baldios & Cita & Testigos \\
\hline $\begin{array}{l}\text { Tierra de indios } \\
\text { excedentarias para } \\
\text { su reproducción social }\end{array}$ & $\begin{array}{l}\text { "siendo de los dichos yndios } \\
\text { los dio por bacas e las bendio" } \\
\text { “unas tierras que [e]staban } \\
\text { en la provinçia de los Charcas } \\
\text { que se debieran dar por vacas }\end{array}$ & $\begin{array}{l}\text { Domingo González, } \\
\text { Pedro Martínez Jarrista }\end{array}$ \\
\hline $\begin{array}{l}\text { Tierra realenga poseída } \\
\text { sin título legítimo }\end{array}$ & $\begin{array}{l}\text { por ser notoriamente defectuoso } \\
\text { el titulo que de [e]llas tenia" }\end{array}$ & Diego de Adrada, escribano \\
\hline
\end{tabular}

Fuente: Información de oficio y parte: Pedro Ozores de Ulloa. Lima, 215, ramo 4. AGI.

Un análisis cualitativo del expediente consultado indica que, más que el término baldío, los actores sociales implicados en el proceso de composición y venta de tierras utilizaron la palabra "vaca". La misma designaba tanto la tierra no concedida como la tierra vacante (aún estando explotada económicamente) que la corona podía (re)adjudicar. Si, como se evidenció en el apartado anterior, Acuña y Muñiz daban interpretaciones parcialmente disímiles de las reales cédulas de 1591 -pues, aunque para ambos las tierras indígenas "excedentarias" no podían readjudicarse en beneficio de la monarquía como tierras vacas, para el primero las tierras que los españoles poseían con títulos defectuosos continuaban siendo tierras realengas, mientras que para Muñiz la posesión podía hacer prescribir los derechos eminentes de la corona-, los vecinos charqueños y el juez comisionado tampoco coincidieron plenamente en torno a la definición de las tierras afectadas en la inspección. Los vecinos charqueños mencionaban las tierras afectadas como vacas, refiriendo a aquellas "sobrantes" de los pueblos de indios y/o a la tierra realenga que los hispano-criollos poseían con título defectuoso (véase cuadro 2). Resulta importante recordar que ambos significados de tierras capaces de ser readjudicadas se podían identificar en las reales cédulas de 1591 y que las primeras habían sido denominadas baldías por el anterior juez de composición, fray Luis López. En cambio, el juez de comisión Osores de Ulloa excluyó de su interpretación las tierras con títulos defectuosos, aplicando la palabra vaca a, por un lado, las tierras que los indios no utilizaban y cedían voluntariamente al rey, y, por el otro, a las tierras sin población ni explotación productiva (véase cuadro 3).

De los 28 casos empíricos identificados en el expediente, trece -es decir, $46 \%$ del total- implicaron el concierto mediante la composición entre los poseedores y el oficial regio (véase cuadro 4). Este accionar coincidía con el espíritu que imbuía las disposiciones regias e implicó la aceptación del pago por composición de los poseedores que ocupaban tierras realengas con títulos defectuosos, sin oír otras posturas. Teniendo en cuenta que estas tierras no fueron conceptuadas como vacas por el juez de composición, es posible que Osores de Ulloa las haya considerado como tierras en las cuales la posesión de buena fe había hecho prescribir los derechos de la monarquía -una interpretación similar a la del deán Muñiz-. Así, por ejemplo, Osores de Ulloa decidió concertar con Juan Díaz Ortiz, relator de la audiencia de Charcas, quien esgrimía la posesión desde hacía dos años a partir de un título defectuoso, por ser una merced del cabildo de La Plata. Sin embargo, la preponderancia de la concertación tampoco debe generalizarse, pues el mismo juez decidió en 


\section{CUADRO 3. TIERRAS VACAS SEGÚN OSORES DE ULLOA, JUEZ DE COMISIÓN. CHARGAS, 1600}

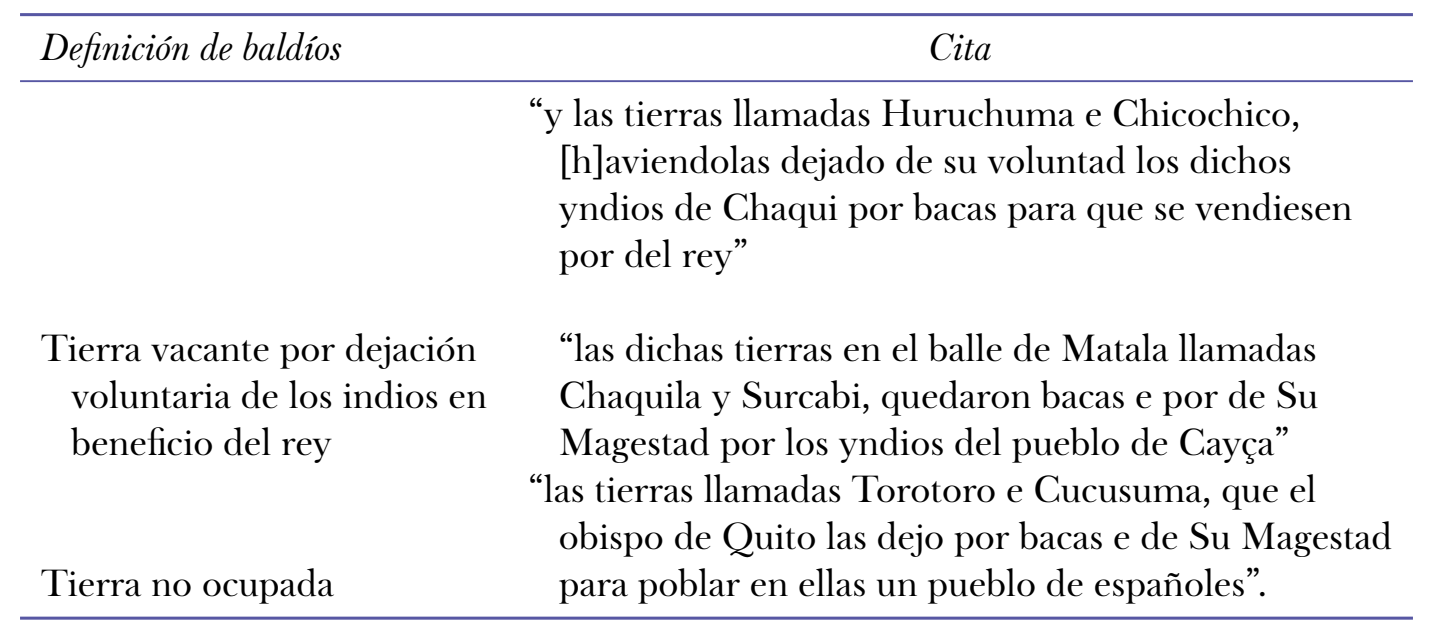

Fuente: Información de oficio y parte: Pedro Ozores de Ulloa. Lima, 215, ramo 4. AGI.

otros casos no confirmar la posesión con títulos legítimos, al declarar las tierras como realengas y componerse con otros españoles. Esto se produjo en los casos imputados en el cargo cuatro -en el cual Osores de Ulloa desposeyó a Rodrigo Bueso para favorecer a Juan de Larrategui- y en el cargo cinco -en el cual de los dos poseedores que pleiteaban derechos posesorios sobre la misma tierra, el juez se compuso con sólo uno de ellos. ${ }^{13}$

Las clases de tierras sujetas a composición incluyeron tierras tanto de uso agrícola como ganadero: se precisa información para $39 \%$ de los 28 casos y en ellos ambos tipos de tierras se encuentran representadas de modo semejante. Asimismo, las cifras muestran que poco más de un tercio de las tierras en disputa tenía algún título de dominio, la mitad de los cuales se había emitido en la década de 1584-1594 y los restantes al momento mismo de la composición como cédulas de merced vicerregia. Lo anterior no debe soslayar que esta imagen congelada oculta la dinámica posterior de ventas sucesivas que, en ocasiones, culminaron en la compra por parte de los repartimientos de indios o de sus caciques gobernadores de las tierras originalmente sustraídas por el juez comisionado, acciones que se comprueban en dos casos empíricos. Así, el expediente da cuenta de que, al decidir los derechos de dominio de la tierra charqueña, el juez de comisión -con o sin conocimiento- no sólo delineaba los derechos dominiales de su distrito, sino que, en ocasiones, garantizaba la adquisición de una renta en metálico al inicial componedor quien obtenía así la legalidad para vender la tierra a su poseedor final o a una cadena de intermediarios hasta su poseedor final.

Una mirada atenta a la semántica de los 28 casos empíricos identificados demuestra que, de acuerdo con los testigos, tres implicaron tierras vacas: dos provenían de tierras "sobrantes" de indios y un caso refería a una posesión española con título defectuoso (véase cuadro 1). En cambio, en la visión del juez y de su asesor, once casos fueron definidos como tierras vacas: diez eran tierras cedidas voluntariamente por los indios o bien sustraídas en el proceso de inspección de los repartimientos indígenas en tanto excedentarias, y en un único caso, como demasía sobre pastos

${ }^{13}$ Información de oficio y parte: Pedro Ozores de Ulloa. Lima, 215, ramo 4, f. 145r y f. 147v. AGI. 


\section{CUADRO 4. TIPOS DE ACGIONES DEL JUEZ DE COMISIÓN OSORES DE ULLOA. CHARCAS, 1600}

\begin{tabular}{lcc}
\hline Acción & $\begin{array}{c}\text { Cantidad } \\
\text { de casos }\end{array}$ & Porcentaje \\
\hline Restitución a repartimientos & & \\
$\quad$ de indios de tierra usurpada & 9 & 32.1 \\
Composición & 7 & 25 \\
Merced vicerregia & & \\
$\quad$ y composición & 6 & 21.4 \\
Venta en subasta & 5 & 18 \\
Restitución de tierra usurpada & & \\
$\quad$ sobre pastos comunes & 1 & 3.5 \\
Totales & 28 & 100 \\
\hline
\end{tabular}

Fuente: Información de oficio y parte: Pedro Ozores de Ulloa. Lima, 215, ramo 4. AGI.

comunes. Así, ajeno a las interpretaciones que aconsejaron al virrey que las tierras indígenas no debían ser conceptuadas como vacantes, Osores de Ulloa vendió tres de dichas tierras -baldías, en la terminología empleada por el previo juez fray Luis López- en subasta pública, seis mercedó y compuso simultáneamente, y en dos ocasiones las compuso con los poseedores hispano-criollos. En ese sentido, y a pesar de que se mencionaron nueve casos empíricos en los cuales el juez comisionado restituyó a los repartimientos de indios tierras ocupadas de hecho por españoles, en líneas generales mediante las composiciones el juez charqueño legitimó el avance del dominio eminente hispano-criollo en detrimento del dominio colectivo indígena, al transferir a la corona los derechos a disponer de algunas de sus tierras. Es interesante notar que el mismo criterio que Osores de Ulloa aplicó en Charcas, asimilando las tierras indígenas sobrantes a tierras a concederse en beneficio de la Real Hacienda, animó al juez comisionado Domingo de Valderrama y también al visitador de la región de Chinchaypucyo (Cusco), Juan López de Arrieta, quien subastó las 208 fanegadas y media de tierras de los indios de la región que consideró sobrantes (Amado, 1998).

Las tierras vendidas por Osores de Ulloa -que suman a las tres que dijo haber subastado, dos ventas que le atribuyeron los testigos- representaron $18 \%$ del total de los casos identificados. En todos ellos, habían sido tierras bajo control comunal indígena, o bien, chacras controladas por un conjunto de líderes indígenas para el sostén de sus obligaciones políticas y/o linajes. Así, si la venta en almoneda se considera el exponente más claro de las tierras baldías cuyo dominio se readjudicó durante la primera composición y venta de tierras, resulta claro que la praxis judicial de Osores de Ulloa no se guió por las interpretaciones que dieron importantes personalidades al virrey. Si bien un grupo de diez poseedores hispano-criollos - uno de ellos, frailes dominicos- perdieron sus derechos posesorios, las tierras subastadas se nutrieron sobre todo de tierras comunales indígenas que se quitaron en el mismo momento de la actuación del juez de comisión, transfiriéndose sus derechos al rey. 
Por último, resulta interesante el conflicto contenido en el caso 17 (véase cuadro 1), de acuerdo con el cual el juez comisionado compuso en su posesión a Pedro Martínez de Jarrista, pero anuló su ocupación de hecho sobre pastos comunes de la Villa Imperial de Potosí. Con ello, Osores de Ulloa reforzó el dominio comunal concejil, pero, en simultáneo, lo cercenó pues compuso -como si esas tierras fuesen realengas- con Luis Hernández, quien reclamaba derechos posesorios sobre una estancia de ganado menor en los mismos pastos comunes. Un ejemplo de la superposición de significados antes mencionado: baldíos como tierra común del concejo y al mismo tiempo como tierra realenga cuyo dominio se readjudicaba -reflejo quizá de la práctica peninsular de otorgamiento de permisos regios para fraccionar parte de las tierras de aprovechamiento común concejil en pos de su conversión en posesiones particulares (Vassberg, 1983).

En síntesis, tomando en cuenta que las relaciones de dominio expresadas en la composición y venta de tierras reflejaron sobre todo las relaciones sociales entabladas en torno a las tierras, se sugiere que, en un contexto de polisemia del término tierras baldías y en el cual el referente material de los mismos era disputado, la práctica judicial de don Pedro Osores de Ulloa expuso el carácter dual del proceso de implementación de las reales cédulas de 1591 en Charcas. Por un lado, como un proceso de redefinición de la relación entre los poseedores hispano-criollos y la corona, en el cual se dio forma a un grupo de poseedores que, con notorias excepciones, logró concertar con la monarquía su posesión irregular de tierra realenga, esgrimiendo títulos defectuosos o la prescripción del dominio regio a partir de su dominio útil de buena fe. Un proceso al que no fue ajena la monarquía, al reiterar en sus disposiciones su ánimo de "legitimar la posesion en que hallaredes a cada uno" (Solano, 1991, p. 271). Por otro lado, como proceso en el cual se cercenaron los derechos territoriales indígenas transfiriendo a la monarquía la capacidad de decidir sobre el destino de las tierras consideradas excedentarias para su reproducción contemporánea o futura. En el proceso, los jueces de comisión tuvieron una participación activa en la conceptualización, selección y venta de los espacios "vacos" o "vacantes" - aun si estaban siendo explotadossusceptibles de enajenarse y venderse al mejor postor como parte del rubro residual que en 1591 se nombró como “todas las demás”. En el distrito de Charcas, importantes antecedentes pudieron haber coadyuvado a las decisiones e interpretaciones del juez de composición, como la real cédula de 1569 dirigida a la audiencia de Charcas, la readjudicación de tierras alejadas de los pueblos de reducción durante la década de 1570-1580, así como la práctica judicial de fray Luis López, quien asimiló las tierras "excedentarias" indígenas a los baldíos. En ese sentido, al ser el juez comisionado Osores de Ulloa al mismo tiempo vecino y "propietario" potosino, su interpretación y ejecución de las reales cédulas de 1591 y de la comisión vicerregia estuvieron imbuidas de concepciones jurídicas socialmente aceptadas, aunque no unívocamente definidas, de los derechos posesorios y de la significación de las tierras baldías en contextos americanos, en cuya construcción y definición desde abajo estuvo activamente implicado.

\section{REFLEXIONES FINALES}

Lejos del significado uniforme brindado en el siglo xvII, el término baldíos y su correlato material en los territorios ultramarinos durante el siglo previo carecen de un significado único y contienen en sí mismos un proceso de construcción disputada de las relaciones posesorias sobre los recursos agrarios en los virreinatos americanos. Si bien la corona otorgó tempranamente tierras a los conquistadores bajo la figura de su reparto gracioso, en la década de 1560 comenzó a centrar su atención en la definición jurídica de los baldíos y en sus aspectos fiscales en sus posesiones ultra- 
marinas. Para el virreinato del Perú, las esferas vicerregias defendieron el uso común y el reparto gracioso de las tierras baldías incluso en la década de 1580, expresando una difusa perspectiva según la cual el dominio regio sobre los baldíos no estaba asentado como para procurar su distribución mediante la compraventa.

En este contexto, las disposiciones regias del 1 de noviembre de 1591, ordenando la composición y venta de tierras en los virreinatos americanos, contuvieron una expresión clara de la legitimidad de la soberanía regia sobre las tierras realengas y baldías, respetando aquellas bajo dominio indígena. La polisemia del término baldío que, retomando las múltiples conceptualizaciones peninsulares, contenían las reales cédulas de 1591, fueron interpretadas tanto por influyentes personalidades consultadas por el virrey de Perú como por los distintos jueces de comisión encargados de ejecutarlas en el terreno. El corpus documental contenido en el juicio de residencia del juez comisionado para el distrito de Charcas, general don Pedro Osores de Ulloa, permitió una aproximación tanto a su praxis judicial relativa a los derechos posesorios como a la semántica del término vaca o vacante, de acuerdo con el uso dado por algunos de los actores sociales implicados en la implementación de las disposiciones -en desmedro de otras definiciones, como aquellas propias de los linajes cacicales, los hatunruna y los indios yanaconas, que aún permanecen opacas. En particular, sobresale la paulatina imposición en la práctica judicial en el territorio del derecho regio a disponer de aquella tierra bajo dominio indígena considerada por el juez "excedentaria" para su reproducción social, a pesar de la severa reprobación de oficiales y canónigos del entorno vicerregio.

La conflictividad inherente al espacio agrario charqueño, sumada a aquella desencadenada por la ejecución de las disposiciones regias, provocó la suspensión de Osores de Ulloa en abril de 1597, mientras arreciaban los procesos judiciales de las comunidades indígenas y de algunos vecinos hispano-criollos ante distintos foros de justicia (Levillier, 1924). Pese a ello, la corona reiteró en 1603 su demanda fiscal sobre las tierras baldías, ordenando por real cédula del 6 de septiembre al virrey del Perú, don Gaspar de Zúñiga, que procurara la venta de los baldíos charqueños (Libros, Registros-Cedularios de Charcas, 1992). Poco menos de medio siglo distaba aún de la afirmación del jurista Solórzano (1972), que asimilaba los baldíos a las tierras por romper y cultivar como regalías del monarca, en un proceso de desplazamiento semántico del que participó sin lugar a dudas la implementación de las composiciones de tierras del siglo xvi y que demanda futuras investigaciones.

\section{LISTA DE REFERENCIAS}

Agüero, A. (2012). Expansión y colonización. En M. Lorente y J. Vallejo (eds.), Manual de historia del derecho (pp. 225-257). Valencia: Tirant lo Blanch.

Albornoz, M. E. (2015). Autoridades locales conflictuadas: Temores y dificultades de jueces territoriales en Chile colonial (1711-1817). Nuevo Mundo Mundos Nuevos, 1-36. Dor: 10.4000/nuevomundo.68292

Amado, D. (1998). Reparto de tierras indígenas y la primera visita y composición general 15911595. Histórica, 22(2), 197-207.

Assadourian, C. (1994). Los derechos a las tierras del Inca y del Sol durante la formación del sistema colonial. En Transiciones hacia el sistema colonial andino (pp. 92-150). Lima: IEP-El Colegio de México. 
Assadourian, C. (2005). Agricultura y tenencia de la tierra antes y después de la Conquista. Población y Sociedad, 12-13, 3-56.

Barnadas, J. M. (1973). Charcas. Orígenes históricos de una sociedad colonial. La Paz: Centro de Investigación y Promoción del Campesinado.

Carmona, M. A. (1995). Usurpaciones de tierras y derechos comunales en Sevilla y su "Tierra" durante el siglo $X V$. Madrid: Ministerio de Agricultura, Pesca y Alimentación.

Carrera, S. (2015). Las composiciones de tierras en los pueblos de indios en dos jurisdicciones coloniales de la Huasteca, 1692-1720. Estudios de Historia Novohispana, 52, 29-50.

Covarrubias, S. de (1943). Tesoro de la lengua castellana, o española. Barcelona: S. A. Horta.

Domínguez, L. (1933). Notas sobre la adquisición de tierras y de frutos en nuestro Derecho Medieval. La presura o escalio. Anuario de historia del derecho español, 10, 287-324.

Encinas, D. (1945). Cedulario indiano. Reproducción facsimil de la edición única de 1596. Madrid: s. e.

García, J. (2012). Auferre rem privati o título versus potestas. La expropiación en los juristas castellanos del ius commune. En S. Dios (ed.), Historia de la propiedad: La expropiación: VII encuentro interdisciplinar, Salamanca, 15-17 de septiembre de 2010 (pp. 99-193). Salamanca: Universidad de Salamanca.

Glave, L. M. (2009). Propiedad de la tierra, agricultura y comercio, 1570-1700: El gran despojo. En C. Contreras (ed.), Compendio de historia económica del Perú (pp. 330-345). Lima: Banco Central de Reserva del Perú/Instituto de Estudios Peruanos.

Glave, L. M. (2014). El arbitrio de tierras de 1622 y el debate sobre las propiedades y los derechos coloniales de los indios. Anuario de Estudios Americanos, 71(1), 79-106. DoI: 10.3989/aeamer.2014.1.04

Izquierdo, J. (2007). En nombre de la comunidad. Antropología de la propiedad en el antiguo régimen. En R. Congost y J. M. Lana (eds.), Campos cerrados, debates abiertos: Análisis histórico y propiedad de la tierra en Europa (siglos XVI-XIX) (pp. 53-73). Pamplona: Universidad Pública de Navarra.

Izquierdo, J. y Sánchez, P. (1998). Orden absolutista y conflicto agrario: Una interpretación institucional de la “venta de baldíos” durante el reinado de Felipe II. En J. Martínez (ed.), Felipe II (1527-1598): Europa y la monarquía católica (pp. 453-470). Madrid: Parteluz.

Jurado, C. (2014a). “(... ) muy mañoso para esto”. Comisiones para don Pedro Osores de Ulloa, segundo juez de composición de tierras de Charcas, 1594-1596. Corpus, 4(2), 1-24. Dor: 10.4000/ corpusarchivos. 1202

Jurado, C. (2014b). Un fiscal al servicio de su majestad: Don Francisco de Alfaro en la Audiencia de Charcas, 1598-1608. Población y Sociedad, 21(1), 99-132.

Jurado, C. (2017). Tejiendo lealtades en Charcas. El segundo juez de visita y composición de tierras en la trama de la dádiva virreinal, 1594-1600. Histórica, 41(1), 11-42. DoI: 10.18800/historica.201701.001

Jurado, C. (2018). La composición como concierto. Prácticas judiciales en espacios rurales durante el primer proceso de visita y composición de tierras y de extranjeros en Charcas. Virreinato del Perú, 1591-1597. Prohistoria. Historia, políticas de la historia, 21(29), 19-42. DOI: 10.35305/prohistoria.vi.1190

Larson, B. (1992). Explotación y economía moral en los Andes del sur: Hacia una reconsideración crítica. Historia Crítica, 6, 75-97. DoI: 10.7440/histcrit6.1992.05

Levillier, R. (1924). Gobernantes del Perú. Cartas y papeles. Madrid: Imprenta de Juan Pueyo. 
Libros, Registros-Cedularios de Charcas (1563-1717). Catálogo. (1992). Buenos Aires: Instituto de Investigaciones de Historia del Derecho.

Luchía, C. (2008). Políticas monárquicas frente a la propiedad comunal en los concejos de realengos castellanos bajomedievales. Hispania, 68(230), 619-646. Dor: 10.3989/hispania.2008.v68.i 230.89

Mariluz, J. (1978). El régimen de la tierra en el Derecho indiano. Buenos Aires: Perrol.

Menegus, M. (1991). Del señorío a la república de indios: El caso de Toluca, 1500-1600. Madrid: Ministerio de Agricultura, Pesca y Alimentación.

Murra, J. V. (1978). La organizacion económica del Estado Inca. Siglo XXI, México.

Niles, S. A. (1987-1989). "Moya” place or yours? Inca private ownership of pleasant places. Nawpa Pacha: Journal of Andean Archaeology, 25/27(1), 189-206. Dor: 10.1179/naw.1987.2527.1.006

Oliveto, L. (2011). De mitmaqkuna incaicos en Tarija a reducidos en La Plata. Tras las huellas de los moyos moyos y su derrotero colonial. Anuario de Estudios Bolivianos, Archivísticos y Bibliográficos, 17, 463-490.

Ots, J. (1946). El régimen de la tierra en la América española durante el periodo colonial. Trujillo: Editora Montalvo.

Ots, J. (1959). España en América. El régimen de tierras en la época colonial. México: Fondo de Cultura Economica.

Palomeque, S. (2010). Los chichas del pueblo de Talina y sus tierras (siglo XvI). Surandino Monográfico, 1(2), 1-77.

Platt, T. (1982). Estado boliviano y ayllu andino tierra y tributo en el norte de Potosí. Lima: Instituto de Estudios Peruanos.

Platt, T., Bouysse-Cassagne, T. y Harris, O. (2006). Qaraqara-Charka: Mallku, inka y rey en la provincia de Charcas (siglos $X V$-XVII): Historia antropológica de una confederación aymara. La Paz: Instituto Francés de Estudios Andinos/Plural editores.

Presta, A. M. (2013). Los valles mesotérmicos de Chuquisaca entre la fragmentación territorial yampara y la ocupación de los migrantes qaraqara y charka en la temprana colonia. En A. M. Presta (ed.), Aportes multidisciplinarios al estudio de los colectivos étnicos surandinos reflexiones sobre Qaraqara-Charka tres años después (pp. 27-59). La Paz-Lima: Plural/Instituto Francés de Estudios Andinos.

Recopilación de Leyes de los Reinos de las Indias, De las Universidades y Estudios Generales y Particulares. Mandadas imprimir y publicar por Carlos II en Madrid, año de 1681 [Proyecto filosofía en español]. (1996). Recuperado 13 de julio de 2021, de https://www.filosofia.org/mfa/fae681a.htm

Río, M. M. (2005). Etnicidad, territorialidad y colonialismo en los Andes: Tradición y cambio entre los Soras de los siglos XVI у хVII (Bolivia). La Paz: Instituto de Estudios Bolivianos.

Saignes, T. (1992). Lobos y ovejas. Formación y desarrollo de los pueblos y comunidades en el Sur Andino (siglos XVI-Xx). En S. Moreno y F. Salomon (eds.), Reproducción y transformación de las sociedades andinas, siglos XVI-XX (pp. 91-136). Quito: Ediciones ABYA-YALA: MLAL, Movimiento Laicos para América Latina.

Schramm, R. (2012). Pocona y Mizque: Transformación de una sociedad indígena en el Perú colonial (Charcas). La Paz: Gobierno Autónomo Municipal de Pocona/umss/InIAm umss/Plural editores.

Solano, F. (1976). El régimen de tierras y la significación de la composición de 1591. Revista de la Facultad de Derecho de México, 26(101-102), 649-670. 
Solano, F. (1991). Cedulario de tierras: Compilación de legislación agraria colonial, 1497-1820. México: Universidad Nacional Autónoma de México.

Solórzano Pereira, J. (1972 [1648]). Politica indiana. Madrid: Biblioteca de Autores Españoles.

Vassberg, D. E. (1983). La venta de tierras baldias: El comunitarismo agrario y la corona de Castilla durante el siglo XVI. Madrid: Ministerio de Agricultura, Pesca y Alimentación.

Wachtel, N. (1980). Los mitimas del valle de Cochabamba: La política de colonización de Wayna Capac. Historia Boliviana, 1(1), 21-5

Archivos

AGI Archivo General de Indias. 